\title{
ANALISIS KEMAMPUAN KOMUNIKASI DAN KERJASAMA SISWA SMA NEGERI 30 JAKARTA MELALUI METODE PEMBELAJARAN PROJEK PADA MATERI HIDROKARBON DAN MINYAK BUMI
}

I Gusti Ayu R.N.A, Tritiyatma H, Irma Ratna K

Jurusan Kimia, Fakultas Matematika dan Ilmu Pengetahuan Alam, Universitas Negeri Jakarta, Jalan Pemuda no 10, Rawamangun 13220, Jakarta, Indonesia.

Corresponding Author: igustichi@gmail.com

\begin{abstract}
Abstrak
Penelitian ini bertujuan mengetahui kemampuan komunikasi dan kerjasama siswa pada saat penerapan metode pembelajaran projek. Subjek penelitian adalah siswa kelas X-7 SMA Negeri 30 Jakarta sebanyak 35 orang. Penelitian dilaksanakan dari April hingga Mei 2013. Metode penelitian yang digunakan adalah deskriptif kualitatif. Kemampuan komunikasi dan kerjasama siswa dinilai menggunakan 3 angket, yaitu: self report, peer review, dan observer. Ketiga angket tersebut mengacu pada 7 indikator, yaitu: tanggung jawab terhadap tugas, menciptakan suasana kondusif saat diskusi, mengambil bagian dalam pengambilan keputusan, menghargai pendapat dan keputusan kelompok, menyesuaikan pilihan kata, volume, dan intonasi suara, menyampaikan ide/hasil diskusi secara jelas, efektif, sistematis, dan meyakinkan, serta menaggapi lawan bicara secara positif. Hasil penelitian ini menunjukkan bahwa kemampuan komunikasi dan kerjasama siswa mengalami peningkatan. Secara keseluruhan pencapaian kemampuan kerjasama sebesar lebih dari 75\% dan kemampuan komunikasi lebih dari $70 \%$.
\end{abstract}

Kata kunci: Kemampuan komunikasi; Kemampuan Kerja Sama; Pembelajaran Projek; Hidrokarbon dan Minyak Bumi

\section{Abstract}

This study aims to determine the ability of communication and student collaboration project when applied learning methods. The subjects were students of class X-7, SMA Negeri 30 Jakarta as many as 35 people. The study was conducted from April to May 2013. The method used is descriptive qualitative. Communication and collaboration capabilities of students assessed using three questionnaires, namely: self-report, peer review, and observer. The third questionnaire refers to the 7 indicators, namely: responsibility for the task, create a conducive atmosphere during the discussion, take part in decision-making, value the opinions and decisions of the group, adjusting word choice, volume, and tone of voice, express ideas / discussion results clearly, effective, systematic, and convincing, and the other person want to respond positively. Results of this study indicate that students' communication skills and increasing cooperation. Overall achievement of joint capabilities by more than $75 \%$ and communication skills more than $70 \%$.

Keywords: Communication skills; Collaboration Capabilities; Learning Project; Hydrocarbons and Petroleum

\section{Pendahuluan}

Persaingan dalam dunia kerja menuntut tenaga kerja yang memiliki profesionalisme dan kemampuan manajerial yang baik. Tenaga kerja yang memiliki kecerdasan emosional (Emotional Quotient) sangat mendukung pemenuhan kebutuhan tersebut dibandingkan dengan kecerdasan intelektual. Kecerdasan emosional mencakup kemampuan mengelola diri sendiri dan orang lain yang disebut juga soft skill, sedangkan kecerdasan intelektual mencakup kemampuan teknis (hard skill).
Berdasarkan hasil survei Nasional Assosiation of Colleges and Employers USA (2012) terhadap 244 pimpinan perusahaan menyatakan bahwa kemampuan teknis (hard skill) bukanlah hal yang dianggap penting dalam dunia kerja, yang jauh lebih penting adalah soft skill antara lain kemampuan komunikasi, kerjasama, kejujuran, motivasi, dan kemampuan beradaptasi. 
Berdasarkan PP No. 19 tahun 2005 Standar Nasional Pendidikan Pasal 6 ayat (1) dinyatakan bahwa, pembelajaran sains

memiliki lingkup untuk mengenal, merespon, mengapresiasi dan memahami sains, mengembangkan kebiasaan berpikir ilmiah seperti berpikir kritis dan kreatif, mandiri, dan memiliki sikap positif. Hal ini membuat sains dapat menjadi salah satu bidang keilmuan yang dapat digunakan untuk mengembangkan soft skill khususnya kemampuan komunikasi dan kerjasama siswa. Kimia merupakan salah satu bidang ilmu sains yang berarti pembelajaran kimiapun dapat dijadikan salah satu cara mengembangkan soft skill. Diantara sekian banyak materi kimia peneliti menyesuaikan materi yang dipilih dengan metode yang akan digunakan dan waktu penelitian.

Penelitian sebelumnya tentang soft skill banyak dilakukan pada materi laju reaksi dan koloid oleh karena itu peneliti akan meneliti pada materi hidrokarbon dan minyak bumi. Materi tersebut dipilih karena memiliki karakteristik yang cocok yaitu menerapkan konsep dalam kehidupan sehari-hari misalnya pada subbab posisi atom karbon, siswa dapat menerapkannya saat menemukan reaksi pembuatan alkohol. Pada materi minyak bumi siswa dapat memahami tentang bilangan oktan yang berguna dalam pemilihan bensin sebagai bahan bakar. Siswa dituntut untuk memahami konsep-konsep penting dalam materi ini sehingga diharapkan siswa secara aktif berkomunikasi dan bekerjasama agar dapat mengerti materi hidrokarbon dan minyak bumi.

Booysen dan Grosser (2008) [1] dan Lavasani (2011) [2] telah melakukan dua penelitian yang berbeda namun menghasilkan satu hal yang sama bahwa penggunaan model pembelajaran kooperatif akan meningkatkan social skill siswa. Social skill merupakan bagian dari soft skill yang menyangkut kemampuan bersosialisasi dengan orang lain oleh karena itu social skill dapat disetarakan dengan interpersonal skill. Berdasarkan dua penelitian tersebut peneliti tertarik untuk menganalisis interpersonal skill siswa khususnya kemampuan komunikasi dan kerjasama, bila diberikan model pembelajaran kooperatif yaitu metode penugasan projek. Metode ini dipilih karena metode ini memiliki tahapan pembelajaran yang menuntut terjadinya komunikasi dan kerjasama antar siswa misalnya saat tahapan mempresentasikan hasil, siswa diharapkan mampu berkomunikasi lisan yang baik serta bekerjasama dalam berbagi tugas. Selain itu metode ini belum pernah dicobakan untuk menganalisis interpersonal skill siswa.

Berdasarkan permasalahan di atas maka peneliti akan melakukan penelitian yang berjudul Analisis Kemampuan Komunikasi dan Kerjasama Siswa SMA Negeri 30 Jakarta dengan Metode Penugasan Projek pada Materi Hidrokarbon dan Minyak Bumi.

\section{Metodologi Penelitian}

Jenis penelitian yang digunakan adalah penelitian deskriptif kualitatif dengan subjek adalah 35 siswa kelas X-7 di SMAN 30 Jakarta. Penelitian dilaksanakan semenjak April hingga Juni 2013.

Metode penelitian yang digunakan dalam penelitian ini adalah metode penelitian deskriptif kualitatif. Mulyana (2004) menyatakan bahwa yang dimaksud dengan analisis deskriptif adalah penelitian yang bertujuan melihat dan menganalisis suatu kondisi dan situasi yang ada sekarang, berupa gambaran-gambaran atau keterikatan antar hal tanpa adanya pengontrolan terhadap hal-hal lainnya. Langkah pertama adalah melakukan pembuatan instrumen penilaian kemampuan

komunikasi dan kerjasama berupa angket melalui penelaahan atau justifikasi pakar (expert judgement). Instrumen yang telah valid dapat digunakan untuk menilai kemampuan komunikasi dan kerjasama siswa kelas X SMAN 30 Jakarta. Langkah selanjutnya mengumpulkan sumber-sumber data berupa profil SMAN 30 Jakarta dan data interpersonal skill siswa hasil penerapan metode penugasan projek pada 
Tabel 1. Kesimpulan Data Indikator 1

\begin{tabular}{|c|c|c|c|c|}
\hline Pengambilan Data & Angket & Persentase & Kriteria & Kesimpulan \\
\hline \multirow{3}{*}{ Pertama } & Self Report & $81 \%$ & Baik & \multirow{2}{*}{ Sangat Baik } \\
\cline { 2 - 4 } & Peer Review & $83 \%$ & Sangat Baik & \\
\cline { 2 - 4 } & Observer & $82 \%$ & Sangat Baik & \\
\hline \multirow{2}{*}{ Kedua } & Self Report & $83 \%$ & Sangat Baik & \multirow{2}{*}{ Sangat Baik } \\
\cline { 2 - 4 } & Peer Review & $83 \%$ & Sangat Baik & \\
\cline { 2 - 4 } & Observer & $83 \%$ & Sangat Baik & \\
\hline \multirow{7}{*}{ Ketiga } & Self Report & $87 \%$ & Sangat Baik & \multirow{2}{*}{ Sangat Baik } \\
\cline { 2 - 4 } & Peer Review & $83 \%$ & Sangat Baik & \\
\cline { 2 - 4 } & Observer & $88 \%$ & Sangat Baik & \\
\hline
\end{tabular}

Tabel 2. Kesimpulan Data Indikator 2

\begin{tabular}{|c|c|c|c|c|}
\hline Pengambilan Data & Angket & Persentase & Kriteria & Kesimpulan \\
\hline \multirow{3}{*}{ Pertama } & Self Report & $74 \%$ & Baik & \multirow{2}{*}{ Baik } \\
\cline { 2 - 4 } & Peer Review & $74 \%$ & Baik & \\
\cline { 2 - 4 } & Observer & $74 \%$ & Baik & \\
\hline \multirow{7}{*}{ Kedua } & Self Report & $75 \%$ & Baik & \multirow{2}{*}{ Baik } \\
\cline { 2 - 4 } & Peer Review & $76 \%$ & Baik & \\
\cline { 2 - 4 } & Observer & $75 \%$ & Baik & \\
\hline \multirow{7}{*}{ Ketiga } & Self Report & $84 \%$ & Sangat Baik & Baik \\
\cline { 2 - 4 } & Peer Review & $76 \%$ & Baik & \\
\cline { 2 - 4 } & Observer & $84 \%$ & Sangat Baik & \\
\hline
\end{tabular}

Tabel 3. Kesimpulan Data Indikator 3

\begin{tabular}{|c|c|c|c|c|}
\hline Pengambilan Data & Angket & Persentase & Kriteria & Kesimpulan \\
\hline \multirow{3}{*}{ Pertama } & Self Report & $81 \%$ & Baik & \multirow{2}{*}{ Baik } \\
\cline { 2 - 4 } & Peer Review & $77 \%$ & Baik & \\
\cline { 2 - 4 } & Observer & $79 \%$ & Baik & \\
\hline \multirow{7}{*}{ Kedua } & Self Report & $82 \%$ & Sangat Baik & \multirow{2}{*}{ Baik } \\
\cline { 2 - 4 } & Peer Review & $80 \%$ & Baik & \\
\cline { 2 - 4 } & Observer & $81 \%$ & Baik & \multirow{2}{*}{ Sangat Baik } \\
\hline \multirow{7}{*}{ Ketiga } & Self Report & $90 \%$ & Sangat Baik & \\
\cline { 2 - 4 } & Peer Review & $80 \%$ & Baik & \\
\cline { 2 - 4 } & Observer & $88 \%$ & Sangat Baik & \\
\hline
\end{tabular}


Tabel 4. Kesimpulan Data Indikator 4

\begin{tabular}{|c|c|c|c|c|}
\hline $\begin{array}{c}\text { Pengambilan } \\
\text { Data }\end{array}$ & Angket & Persentase & Kriteria & Kesimpulan \\
\hline \multirow{4}{*}{ Pertama } & Self Report & $75 \%$ & Baik & \multirow{2}{*}{ Baik } \\
\cline { 2 - 4 } & Peer Review & $73 \%$ & Baik & \\
\cline { 2 - 4 } & Observer & $73 \%$ & Baik & \\
\hline \multirow{3}{*}{ Kedua } & Self Report & $79 \%$ & Baik & \multirow{2}{*}{ Baik } \\
\cline { 2 - 4 } & Peer Review & $74 \%$ & Baik & \\
\cline { 2 - 4 } & Observer & $77 \%$ & Baik & \multirow{2}{*}{ Sangat Baik } \\
\hline \multirow{3}{*}{ Ketiga } & Self Report & $85 \%$ & Sangat Baik & \\
\cline { 2 - 4 } & Peer Review & $74 \%$ & Baik & \\
\cline { 2 - 4 } & Observer & $84 \%$ & Sangat Baik & \\
\hline
\end{tabular}

Tabel 5. Kesimpulan Data Indikator 5

\begin{tabular}{|c|c|c|c|c|}
\hline $\begin{array}{c}\text { Pengambilan } \\
\text { Data }\end{array}$ & Angket & Persentase & Kriteria & Kesimpulan \\
\hline \multirow{3}{*}{ Pertama } & Self Report & $79 \%$ & Baik & \multirow{2}{*}{ Baik } \\
\cline { 2 - 4 } & Peer Review & $77 \%$ & Baik & \\
\cline { 2 - 4 } & Observer & $78 \%$ & Baik & \\
\hline \multirow{3}{*}{ Kedua } & Self Report & $80 \%$ & Baik & \multirow{2}{*}{ Baik } \\
\cline { 2 - 4 } & Peer Review & $78 \%$ & Baik & \\
\cline { 2 - 4 } & Observer & $79 \%$ & Baik & \\
\hline \multirow{3}{*}{ Ketiga } & Self Report & $88 \%$ & Sangat Baik & \multirow{2}{*}{ Sangat Baik } \\
\cline { 2 - 4 } & Peer Review & $78 \%$ & Baik & \\
\cline { 2 - 4 } & Observer & $87 \%$ & Sangat Baik & \\
\hline
\end{tabular}

Tabel 6. Kesimpulan Data Indikator 6

\begin{tabular}{|c|c|l|l|c|}
\hline $\begin{array}{c}\text { Pengambilan } \\
\text { Data }\end{array}$ & Angket & Persentase & Kriteria & Kesimpulan \\
\hline \multirow{4}{*}{ Pertama } & Self Report & $61 \%$ & urang Baik & \multirow{2}{*}{ Baik } \\
\cline { 2 - 4 } & Peer Review & $67 \%$ & Baik & \\
\cline { 2 - 4 } & Observer & $64 \%$ & Baik & \multirow{2}{*}{ Baik } \\
\hline \multirow{7}{*}{ Kedua } & Self Report & $71 \%$ & Baik & \\
\cline { 2 - 4 } & Peer Review & $72 \%$ & Baik & \multirow{2}{*}{ Baik } \\
\cline { 2 - 4 } & Observer & $72 \%$ & Baik & \\
\hline \multirow{3}{*}{ Ketiga } & Self Report & $81 \%$ & Baik & Baik \\
\cline { 2 - 4 } & Peer Review & $72 \%$ & Baik & \\
\cline { 2 - 4 } & Observer & $81 \%$ & & \\
\hline
\end{tabular}


komunikasi dan kerjasama berupa angket melalui penelaahan atau justifikasi pakar (expert judgement). Instrumen yang telah valid dapat digunakan untuk menilai kemampuan komunikasi dan kerjasama siswa kelas X SMAN 30 Jakarta. Langkah selanjutnya mengumpulkan sumber-sumber data berupa profil SMAN 30 Jakarta dan data interpersonal skill siswa hasil penerapan metode penugasan projek pada

Indikator yang dicapai yaitu: (1) tanggung jawab terhadap tugas, (2) menciptakan suasana kondusif saat diskusi, (3) mengambil bagian dalam pengambilan keputusan, (4) menghargai pendapat dan keputusan kelompok, (5) menyesuaikan pilihan kata, volume, dan intonasi suara, (6) menyampaikan ide/hasil diskusi secara jelas, efektif, sistematis, dan meyakinkan, (7) menanggapi lawan bicara secara positif.

Menurut Ahmadi dan Prasetyo (1997) [4] langkah-langkah pembelajaran dengan menggunakan metode projek sebagai berikut: (1) penyelidikan (exploration), (2) penyajian bahan baru (presentation), (3) pengumpulan keterangan atau data (asimilasi), mengorganisasikan data (organization), (5) mengungkapkan kembali (recitation). Metode ini memantapkan pengetahuan yang diperoleh siswa dan menyalurkan minat serta melatih siswa menelaah suatu materi pelajaran dengan wawasan yang lebih luas.

Data yang diperoleh dalam penelitian ini adalah hasil angket pelaporan diri (self report), angket penilaian sebaya (peer review), dan angket observasi

\section{Hasil Penelitian dan Pembahasan}

\section{A. Deskripsi Data}

Penelitian ini bertujuan untuk mengetahui kemampuan komunikasi dan kerjasama siswa kelas X-7 SMA Negeri 30 Jakarta setelah dilaksanakannya pembelajaran kimia materi Hidrokarbon dan Minyak Bumi dengan metode pembelajaran projek. Penelitian ini dibagi menjadi 2 tahap, yaitu:

\section{Tahap Persiapan}

Pertama peneliti melakukan observasi kegiatan pembelajaran di dalam kelas yang akan diteliti. Hasil yang diperoleh dari kegiatan observasi adalah siswa-siswi di kelas $X-7$ cenderung diam saat pembelajaran berlangsung namun sangat ribut saat pembelajaran berakhir. Langkah selanjutnya peneliti merancang kegiatan pembelajaran yang disesuaikan dengan keinginan siswa, yaitu pembelajaran yang menyenangkan dan efektif (rancangan kegiatan pembelajaran terlampir). Kemudian peneliti memilih guru model yang akan melaksanakan kegiatan pembelajaran serta menyiapkan tiga orang observer untuk membantu menilai kemampuan komunikasi dan kerjasama siswa menggunakan angket yang telah disiapkan.

\section{Tahap Pelaksanaan}

Penelitian ini dilaksanakan mulai tanggal 23 April-14 Agustus 2013 setiap hari Selasa dan Rabu. Jumlah pertemuan yang dilaksanakan sebanyak delapan pertemuan dengan jumlah jam pelajaran selama $12 \times 45$ menit. Peneliti berperan sebagai observer dan guru model yang mengajar adalah mahasiswa rekan peneliti.

Pada pertemuan pertama peneliti, guru model, serta observer didampingi guru kimia kelas $X-7$ masuk ke kelas dan melakukan perkenalan. Kemudian guru model memberikan angket self report untuk menilai kemampuan komunikasi dan kerjasama sebelum dilaksanakannya pembelajaran. Kemudian guru membagi kelas menjadi tujuh kelompok dengan cara berhitung agar pembagian kelompok adil dalam hal jumlah dan pemilihan anggota. Setelah siswa duduk sesuai kelompoknya guru mulai menjelaskan tentang kekhasan atom karbon, kedudukan atom karbon dalam rantai karbon dan tata nama hidrokarbon. Pertemuan kedua diawali dengan memposisikan siswa duduk sesuai kelompoknya lalu membahas LDS pertemuan sebelumnya. Pertemuan ketiga dimulai dengan guru menjelaskan tentang isomer hidrokarbon. Siswa yang duduk dikelompoknya sebagian 
besar mendengarkan dan mencatat, namun ada beberapa siswa yang melakukan kegiatan yang tidak ada hubungannya dengan pembelajaran. Pada pertemuan keempat siswa mengumpulkan tugas yang diberikan sebelumnya lalu mulai mengerjakan projeknya kembali. Pada pertemuan kelima guru menjelaskan tentang reaksi hidrokarbon serta mengulang kembali tentang isomer. Pertemuan keenam dimulai dengan menyelesaikan projek masing-masing kelompok kemudian presentasi. Pertemuan ketujuh diawali dengan tanya jawab seputar minyak bumi. Selanjutnya adalah presentasi kelompok 4 dan 5 secara bersamaan. Pertemuan kedelapan hanya dilaksanakan ulangan saja selama 40 menit.

\section{B. Analisis Data}

Data yang diperoleh untuk menilai kemampuan komunikasi dan kerjasama siswa diambil dari tiga angket, yaitu self report, peer review, dan observasi. Data diambil saat pembelajaran menggunakan metode projek selama materi hidrokarbon dan minyak bumi. Pengambilan data dilakukan sebanyak tiga kali yaitu pada pertemuan pertama, keempat, dan ketujuh. Ketiga jenis angket tersebut digunakan untuk triangulasi data agar data yang diperoleh tidak bias.

1. Kemampuan tanggung jawab terhadap tugas

Pencapaian indikator 1 dari angket self report pada pengambilan data pertama sebesar $81 \%$, kedua sebesar $83 \%$, dan ketiga sebesar $87 \%$. Berdasarkan angket peer review, pada pengambilan data pertama menghasilkan pencapaian sebesar 83\%, kedua sebesar $83 \%$ dan ketiga sebesar 83\%. Hal ini mungkin disebabkan oleh siswa tidak mengisi angket peer review dengan serius. Dari hasil angket peer review terlihat siswa menilai teman sekelompoknya dengan nilai yang sama tiap pertemuan padahal menurut observer siswa mengalami peningkatan. Berdasarkan angket observer didapatkan hasil pada pengambilan data pertama sebesar $82 \%$, kedua sebesar $83 \%$ dan ketiga sebesar $88 \%$. Terdapat peningkatan dari pengambilan data pertama hingga ketiga pada self report dan observer, sedangkan berdasarkan peer review persentase yang didapat adalah tetap, yaitu $83 \%$

2. Kemampuan menciptakan suasana diskusi yang kondusif

Pencapaian indikator 2 dari angket self report pada pengambilan data pertama sebesar $74 \%$, kedua sebesar 75\%, dan ketiga sebesar $84 \%$. Berdasarkan angket peer review, pada pengambilan data pertama menghasilkan pencapaian sebesar $74 \%$, kedua sebesar $76 \%$ dan ketiga sebesar $76 \%$. Pada pengambilan data kedua dan ketiga hasil yang didapat adalah tetap. Hal ini mungkin disebabkan oleh siswa tidak mengisi angket peer review dengan serius. Dari hasil angket peer review terlihat siswa menilai teman sekelompoknya dengan nilai yang sama tiap pertemuan padahal menurut observer siswa mengalami peningkatan. Berdasarkan angket observer didapatkan hasil pada pengambilan data pertama sebesar $74 \%$, kedua sebesar $75 \%$ dan ketiga sebesar $84 \%$. Terdapat peningkatan dari pengambilan data pertama hingga ketiga pada self report dan observer.

3. Kemampuan mengambil bagian dalam pengambilan keputusan

Pencapaian indikator 3 dari angket self report pada pengambilan data pertama sebesar $81 \%$, kedua sebesar $82 \%$, dan ketiga sebesar $90 \%$. Berdasarkan angket peer review, pada pengambilan data pertama menghasilkan pencapaian sebesar $77 \%$, kedua sebesar $80 \%$ dan ketiga sebesar $80 \%$. Pada pengambilan data kedua dan ketiga hasil yang didapat adalah tetap. Hal ini mungkin disebabkan oleh siswa tidak mengisi angket peer review dengan serius. Dari hasil angket peer review terlihat siswa menilai teman sekelompoknya dengan nilai yang sama tiap pertemuan padahal menurut observer siswa mengalami peningkatan Berdasarkan angket observer didapatkan 
Tabel 7. Kesimpulan Data Indikator 7

\begin{tabular}{|c|c|l|c|c|}
\hline $\begin{array}{c}\text { Pengambilan } \\
\text { Data }\end{array}$ & Angket & Persentase & Kriteria & Kesimpulan \\
\hline \multirow{4}{*}{ Pertama } & Self Report & $75 \%$ & Baik & \multirow{2}{*}{ Baik } \\
\cline { 2 - 4 } & Peer Review & $77 \%$ & Baik & \\
\cline { 2 - 4 } & Observer & $76 \%$ & Baik & \multirow{2}{*}{ Baik } \\
\hline \multirow{3}{*}{ Kedua } & Self Report & $82 \%$ & Sangat Baik & \multirow{2}{*}{ Sangat Baik } \\
\cline { 2 - 4 } & Peer Review & $79 \%$ & Baik & \\
\cline { 2 - 4 } & Observer & $80 \%$ & Baik & \\
\cline { 2 - 4 } & Self Report & $89 \%$ & Sangat Baik & Baik \\
\cline { 2 - 4 } & Peer Review & $79 \%$ & Sangat Baik & \\
\cline { 2 - 4 } & Observer & $87 \%$ & \multicolumn{2}{|c}{} \\
\hline
\end{tabular}

3. Kemampuan mengambil bagian dalam pengambilan keputusan

Pencapaian indikator 3 dari angket self report pada pengambilan data pertama sebesar $81 \%$, kedua sebesar 82\%, dan ketiga sebesar 90\%. Berdasarkan angket peer review, pada pengambilan data pertama menghasilkan pencapaian sebesar 77\%, kedua sebesar $80 \%$ dan ketiga sebesar $80 \%$. Pada pengambilan data kedua dan ketiga hasil yang didapat adalah tetap. Hal ini mungkin disebabkan oleh siswa tidak mengisi angket peer review dengan serius. Dari hasil angket peer review terlihat siswa menilai teman sekelompoknya dengan nilai yang sama tiap pertemuan padahal menurut observer siswa mengalami peningkatan. Berdasarkan angket observer didapatkan hasil pada pengambilan data pertama sebesar 79\%, kedua sebesar $81 \%$ dan ketiga sebesar 88\%. Terdapat peningkatan dari pengambilan data pertama hingga ketiga pada self report dan observer.

4. Kemampuan menghargai hasil dan keputusan kelompok

Pencapaian indikator 4 dari angket self report pada pengambilan data pertama sebesar 75\%, kedua sebesar 79\%, dan ketiga sebesar 85\%. Berdasarkan angket peer review, pada pengambilan data pertama menghasilkan pencapaian sebesar $73 \%$, kedua sebesar $74 \%$ dan ketiga sebesar 74\%. Pada pengambilan data kedua dan ketiga hasil yang didapat adalah tetap. Hal ini mungkin disebabkan oleh siswa tidak mengisi angket peer review dengan serius. Dari hasil angket peer review terlihat siswa menilai teman sekelompoknya dengan nilai yang sama tiap pertemuan padahal menurut observer siswa mengalami peningkatan. Berdasarkan angket observer didapatkan hasil pada pengambilan data pertama sebesar $73 \%$, kedua sebesar $77 \%$ dan ketiga sebesar $84 \%$. Terdapat peningkatan dari pengambilan data pertama hingga ketiga pada self report dan observer.

5. Kemampuan menyesuaikan pilihan kata, volume dan intonasi suara

Pencapaian indikator 5 dari angket self report pada pengambilan data pertama sebesar 79\%, kedua sebesar 80\%, dan ketiga sebesar $88 \%$. Berdasarkan angket peer review, pada pengambilan data pertama menghasilkan pencapaian sebesar 77\%, kedua sebesar 78\% dan ketiga sebesar 78\%. Pada pengambilan data kedua dan ketiga hasil yang didapat adalah tetap. Hal ini mungkin disebabkan oleh siswa tidak mengisi angket peer review dengan serius. Dari hasil angket peer review terlihat siswa menilai teman sekelompoknya dengan nilai yang sama tiap pertemuan padahal menurut observer siswa mengalami peningkatan. 
Berdasarkan angket observer didapatkan hasil pada pengambilan data pertama sebesar $78 \%$, kedua sebesar $79 \%$ dan ketiga sebesar $87 \%$. Terdapat peningkatan dari pengambilan data pertama hingga ketiga pada self report dan observer.

6. Kemampuan menyampaikan ide secara jelas, efektif, sistematis, dan meyakinkan

Pencapaian indikator 6 dari angket self report pada pengambilan data pertama sebesar $61 \%$, kedua sebesar $71 \%$, dan ketiga sebesar $81 \%$. Berdasarkan angket peer review, pada pengambilan data pertama menghasilkan pencapaian sebesar $67 \%$, kedua sebesar $72 \%$ dan ketiga sebesar $72 \%$. Pada pengambilan data kedua dan ketiga hasil yang didapat adalah tetap. Hal ini mungkin disebabkan oleh siswa tidak mengisi angket peer review dengan serius. Dari hasil angket peer review terlihat siswa menilai teman sekelompoknya dengan nilai yang sama tiap pertemuan padahal menurut observer siswa mengalami peningkatan. Berdasarkan angket observer didapatkan hasil pada pengambilan data pertama sebesar $64 \%$, kedua sebesar $72 \%$ dan ketiga sebesar $81 \%$. Terdapat peningkatan dari pengambilan data pertama hingga ketiga pada self report dan observer.

7. Kemampuan menanggapi lawan bicara secara positif

Pencapaian indikator 7 dari angket self report pada pengambilan data pertama sebesar $75 \%$, kedua sebesar $82 \%$, dan ketiga sebesar $89 \%$. Berdasarkan angket peer review, pada pengambilan data pertama menghasilkan pencapaian sebesar $77 \%$, kedua sebesar $79 \%$ dan ketiga sebesar $79 \%$. Pada pengambilan data kedua dan ketiga hasil yang didapat adalah tetap. Hal ini mungkin disebabkan oleh siswa tidak mengisi angket peer review dengan serius. Dari hasil angket peer review terlihat siswa menilai teman sekelompoknya dengan nilai yang sama tiap pertemuan padahal menurut observer siswa mengalami peningkatan.
Berdasarkan angket observer didapatkan hasil pada pengambilan data pertama sebesar $76 \%$, kedua sebesar $80 \%$ dan ketiga sebesar $87 \%$. Terdapat peningkatan dari pengambilan data pertama hingga ketiga pada self report dan observer.

\section{Kesimpulan dan Saran}

\section{A. Kesimpulan}

Berdasarkan hasil penelitian yang telah dilakukan di SMA Negeri 30 Jakarta terhadap siswa kelas $\mathrm{X}-7$ dengan jumlah siswa 35 orang, diperoleh kesimpulan bahwa kemampuan komunikasi dan kerjasama siswa yang berdasarkan tujuh indikator dapat berkembang setelah dilaksanakannya pembelajaran dengan metode projek pada materi hidrokarbon dan minyak bumi. Indikator yang tercapai yaitu: tanggung jawab terhadap tugas, menciptakan suasana kondusif saat diskusi, mengambil bagian dalam pengambilan keputusan, menghargai pendapat dan keputusan kelompok, menyesuaikan pilihan kata, volume, dan intonasi suara, menyampaikan ide/hasil diskusi secara jelas, efektif, sistematis, dan meyakinkan, serta menanggapi lawan bicara secara positif.

Penerapan metode pembelajaran metode projek mendorong siswa untuk bekerjasama dengan anggota kelompoknya agar tercipta suatu produk yang disepakati oleh kelompok tersebut. Metode ini juga mendorong siswa untuk dapat mempresentasikan hasil dari diskusi dengan baik.

Hal ini dapat dilihat dari kesimpulan tiap indikator yang menyatakan bahwa dari pertemuan pertama hingga ketiga mengalami peningkatan. Kriteria akhir semua indikator berada di level baik bahkan untuk indikator 3 berada pada level sangat baik. Secara keseluruhan pencapaian kemampuan kerjasama sebesar lebih dari $77 \%$ dan kemampuan komunikasi lebih dari $70 \%$.

\section{B. Saran}

Beberapa metode lain dapat digunakan untuk melihat kemampuan komunikasi dan kerjasama siswa, yang mungkin dapat diterapkan pula pada materi kimia yang lain. Kemampuan komunikasi dan kerjasama bukan kemampuan yang bisa dilihat dan 
dikembangkan dalam waktu yang singkat sehingga disarankan untuk menambah waktu penelitian. Menilai kemampuan komunikasi dan kerjasama siswa juga memerlukan instrumen yang tepat sehingga disarankan untuk membuat instrumen yang lebih menyeluruh agar dapat efektif menilai kemampuan tersebut.

\section{DAFTAR PUSTAKA}

[1] Grosser, M. 2008. Enhancing Social Skills through Cooperative. The Journal for Transdisciplinary Research in Southern Africa.377-399.

[2] Lavasani, M. G. 2011. Cooperative Learning and Social Skills. Cypriot Journal of Educational Sciences, 186-193.

[3] Mulyana, D. 2004. Metode Penelitian Kualitatif. Bandung: Remaja Rosda Karya.

[4] Ahmadi, A. dan Prasetyo, J. T. 1997. Strategi Belajar Mengajar. Bandung: Pustaka Setia. 